\title{
Biodegradation of Endosulfan by Pseudomonas fluorescens
}

\author{
K. Jesitha • K. M. Nimisha • C. M. Manjusha • \\ P. S. Harikumar
}

Received: 6 July 2014 / Accepted: 17 January 2015 / Published online: 1 February 2015

(C) Springer International Publishing Switzerland 2015

\begin{abstract}
The endosulfan-degrading bacterial strain Pseudomonas fluorescens was isolated, and degradation of endosulfan by freely suspended and calcium-alginate entrapped bacterial cells were investigated in batch as well as in packed bed column studies. Freely suspended Pseudomonas fluorescens cells with biomass maximum $\mathrm{OD} / \mathrm{OD}_{0}$ value of 1.68 at $610 \mathrm{~nm}$ could degrade endosulfan with an initial concentration of $350.24 \pm 0.83 \mu \mathrm{g} / \mathrm{L}$ efficiently within 12 days, thus utilising endosulfan as the sole carbon and energy source. Degradation of endosulfan occurred concomitantly with bacterial growth. The bacteria immobilised in Caalginate beads in batch shake flask system were tested for their ability to degrade endosulfan at different concentrations $(350.24 \pm 0.83,450.39 \pm 1.95$ and $550.85 \pm 1.84 \mu \mathrm{g} / \mathrm{L})$. A total of $125 \mathrm{~mL}$ of Broth minimal medium of $\mathrm{pH} 7$ was inoculated with $5 \mathrm{~g}$ of wet Ca-alginate beads (derived from a $3-\mathrm{mL}$ cell suspension of $0.72 \mathrm{OD}$ at $610 \mathrm{~nm}$ ) for the study. Almost similar trends of degradation efficiencies were shown by the immobilised cells toward different concentrations of endosulfan. The complete removal of alpha and beta-isomers of endosulfan at different initial endosulfan concentrations was observed between 9 and 11 days of the experiment. Additionally, the degradation rate in batch reactors with Ca-alginate-immobilised cells also derived from a $3-\mathrm{mL}$ cell suspension of $0.72 \mathrm{OD}$ at $610 \mathrm{~nm}$ was tested and found to be marginally higher than that of free cells. Ca-alginate immobilised cells in packed bed reactors operated in a semi-continuous mode could degrade toxic alpha and beta-isomers of endosulfan $(350.38 \pm 1.18 \mu \mathrm{g} / \mathrm{L})$ within 6 days. Thus, the method proved effective for biodegradation of endosulfan. The metabolites formed indicated that the degradation of the pesticide follows a hydrolytic pathway.
\end{abstract}

Keywords Biodegradation Endosulfan Pseudomonas fluorescens $\cdot$ Ca-alginate beads

\section{Introduction}

Rapid industrialisation and uncontrolled extraction of natural resources results in generation of large amounts of toxic chemicals which pollute the soil and water. Decontamination of polluted sites requires state-of art and cost effective technologies to convert them to safe for human habitations (Prasad 2011). Endosulfan, which is a chlorinated pesticide, has been

K. Jesitha $\cdot$ K. M. Nimisha $\cdot$ C. M. Manjusha $\cdot$ P. S. Harikumar $(\bowtie)$

Centre for Water Resources Development and Management, Kozhikode 673 571, India

e-mail: drpshari@yahoo.co.in 
widely used and is persistent for a period of 9 months to 6 years (USEPA 2002). Monitoring of endosulfan has been reported by many authors, worldwide. A study conducted in China, as part of monitoring of 141 soil samples, reported a concentration of total endosulfan ranging from below detection limit to $19,000 \mathrm{pg} / \mathrm{g}$ (Jia et al. 2010). The National Institute of Occupational Health did a study in Padre Village of Kasaragod District and detected the presence of endosulfan residues in water, pond sediment and soil samples (NIOH 2002). Endosulfan is an endocrine disruptor and a genotoxin (Fernandez 2007). Endosulfan was aerially sprayed for many years in the cashew plantations of Kasaragod district of Kerala, India, though it was later discontinued. The persistence of endosulphan was studied by many authors and found to depend on climatic conditions and certain physico-chemical characteristics, like $\mathrm{pH}$ and organic matter content of the soil in the area (Harikumar et al. 2014; Leena et al. 2011; Zhao et al. 2009). The permissible limit for endosulfan in drinking water as per Bureau of Indian Standards is $0.4 \mu \mathrm{g} / \mathrm{L}$ (BIS 2012) and the permissible limit in lakes, rivers and streams as per United States Environmental Protection Agency is $74 \mu \mathrm{g} / \mathrm{L}$ (USEPA 2002).

Only a small portion of the pesticides applied in agriculture field is used by the crops. The remaining portion mostly ends up in the water, soil or in the air. Pesticides, if continuously used, may cause possibly harmful and unpredictable health impacts (Santacruz et al. 2005). The physical processes which have been used for the decontamination of hazardous wastes have been reported to be uneconomical and unsustainable. Hence, biological methods have been introduced, which were found to be socially acceptable and cost effective. Different types of microbial cultures have been introduced for the degradation of organophosphates, PCBs, PAHs Endrin etc. (Sinha et al. 2009). The degradation of pesticides occurs through complex biochemical reactions. To understand the mechanism behind the biodegradation of pesticides by enzyme catalysis, further research is needed (Meleiro-Porto et al. 2011).

Immobilisation of the pure cultures may help to improve the bioremediation potential, as immobilised cells have prolonged microbial cell viability and improved capacity to tolerate higher concentrations of pollutants (Richins et al. 2000; Chen and Georgiou 2002).

In the present study, the bacterial strain Pseudomonas fluorescens was isolated and tested for its potential to degrade endosulfan. The main objective of the work was to develop the basic design of an efficient bioreactor with immobilised Pseudomonas fluorescens for the degradation of endosulfan. The degrees of endosulfan degradation for both isomers and the metabolites present at different intervals were studied.

\section{Materials and Methods}

\subsection{Reagents and Standards}

Technical grade endosulfan (endosulfan alpha + beta) and its metabolites (endosulfan sulphate, endosulfan ether, endosulfan lactone, and endosulfan diol) required for the study were obtained from E. Merck (Germany). All the reagents used were of analytical grade.

\subsection{Preparation of Standard Endosulfan Solution}

An endosulfan solution with an initial concentration of $1 \mathrm{ppm}$ was prepared by diluting $5 \mathrm{~mL}$ of 100 ppm stock solution to $500 \mathrm{~mL}$ with chromatographic grade $\mathrm{n}$-hexane. During different stages of the experiment, the test solution of desired concentration was prepared by diluting the $1 \mathrm{ppm}$ solution with hexane. 


\subsection{Isolation and Identification of Pseudomonas fluorescens}

A pure culture of Pseudomonas fluorescens capable of degrading endosulfan was isolated from the talc-based formulation of Pseudomonas fluorescens, the Bio control Agent developed by the Kerala Agricultural University for the management of disease and promotion of growth in crop plants. The enrichment culture technique was used for the isolation of bacterial strain capable of utilising endosulfan as its sole carbon source and to obtain highly resistant bacterial cells (Awasthi et al. 1997). The colonies of microbes that showed endosulfan toxicity resistance and abundant growth were isolated. Isolates were purified by streaking three times on fresh plates, and selected isolates of bacteria were preserved on nutrient agar medium. Morphological, physiological and biochemical tests were conducted to identify the isolated species.

Gram staining was used to study the morphological characters of the isolates. Depending upon the Gram reaction, the organisms were identified as Gram positive or Gram negative. Depending upon the shape, the organism was identified as cocci or bacilli. For the identification of Pseudomonas fluorescens, certain biochemical tests, viz. gelatin liquefaction, starch hydrolysis, catalase test, oxidase test, IAA production, siderophore production and hydrogen cyanide production were conducted (Buchannan and Gibbson 1974; Meera and Balabaskar 2012). Also 16S rRNA sequencing was performed to confirm the identity of the isolated microbial species. Biochemical tests were also conducted during different stages throughout the experiment to confirm the presence of the same species.

\subsection{Inoculum Preparation}

The media used for developing the seed culture for use in biodegradation experiments contained a broth minimal medium (non-carbon medium having the composition $\mathrm{KH}_{2} \mathrm{PO}_{4}$ $1.0 \mathrm{~g}, \mathrm{~K}_{2} \mathrm{HPO}_{4} 1.0 \mathrm{~g}, \mathrm{NH}_{4} \mathrm{NO}_{3} 1.0 \mathrm{~g}, \mathrm{MgSO}_{4} 0.2 \mathrm{~g}, \mathrm{CaCl}_{2} 0.02 \mathrm{~g}, \mathrm{Fe}\left(\mathrm{SO}_{4}\right) 0.01 \mathrm{~g}$, and doubledistilled water $1 \mathrm{~L}$ ) with the $\mathrm{pH}$ maintained at 6.8 and endosulfan isomers at a concentration of $100 \mu \mathrm{g} / \mathrm{L}$ as the sole carbon and energy source. The seed culture medium $(500 \mathrm{~mL})$ was taken in a $1000 \mathrm{~mL}$ Erlenmeyer flask and inoculated with a loop full of the culture, freshly grown on agar slants and incubated for 5 days at $28{ }^{\circ} \mathrm{C}$ and $150 \mathrm{rpm}$. The cells were harvested by centrifugation at $8000 \mathrm{rpm}$ for $10 \mathrm{~min}$ and washed by suspending in sterile deionised water and re-pelleting by centrifugation. These cells were used for the degradation studies as free cells or as gel-entrapped biomass. The growth of Pseudomonas fluorescens cells was monitored by recording the optical density of the culture at a wavelength of $610 \mathrm{~nm}$ for different time intervals during the study. The optimal conditions for bacterial growth, including temperature, $\mathrm{pH}$ and initial endosulfan concentration, were fixed as per Santacruz et al. (2005) and Kumar and Philip (2006a, b).

\subsection{Immobilisation of Whole Cells}

The alginate entrapment of bacterial cells was performed as per the method described by Kierstan and Coughlan (1985). Immobilised cells for the batch degradation studies were prepared by adding $3 \mathrm{~mL}$ of the cell suspension having a $0.72 \mathrm{OD}$ at $610 \mathrm{~nm}$ (cell content in terms of wet weight was equivalent to $0.068 \mathrm{~g}$ of cells) to $25 \mathrm{~mL}$ of a $4 \% \mathrm{w} / v$ sterilised sodium alginate solution. For the packed column study, $15 \mathrm{~mL}$ of the cell suspension at the same optical density (cell content in terms of wet weight was equivalent to $0.34 \mathrm{~g}$ of cells) was mixed with $300 \mathrm{~mL}$ of a $4 \% \mathrm{w} / v$ sterilised Na-alginate solution. The solutions were subsequently stirred for $10 \mathrm{~min}$, and the resulting alginate/cell mixtures were dripped into a 
beaker containing ice cold sterile $0.3 \mathrm{M} \mathrm{CaCl}_{2}$ through a needleless $10 \mathrm{~mL}$ syringe from a height of $5 \mathrm{~cm}$. The prepared beads were cured in $\mathrm{CaCl}_{2}$ solution for $12 \mathrm{~h}$ at room temperature, and then washed with the sterilised saline solution $(0.85 \% \mathrm{w} / \mathrm{v}, \mathrm{pH} 7.0)$ and stored in a $\mathrm{CaCl}_{2}$ solution at $4{ }^{\circ} \mathrm{C}$ for further use.

The inner and outer surface morphologies of the Ca-alginate gel beads and Pseudomonas fluorescens cell-immobilised beads were characterised by scanning electron microscopy (SEM). Bacterial colony formation inside the Ca-alginate beads was confirmed using SEM images.

\subsection{Determination of Cfu Count/Bead}

The number of immobilised cells on Ca-alginate beads was determined by the crushing method (Tewari and Malviya 2002). In the crushing method, a $1 \mathrm{~g}$ uniform round bead was finely crushed in $10 \mathrm{~mL}$ sterile distilled water. The suspension was serially diluted to $10^{-7}$, and the cfu was calculated on agar medium using the suspension by serial dilution plate count method.

\subsection{Batch Degradation Study of Endosulfan with Free Cells}

Pure cultures were grown in broth minimal medium for 5 days, centrifuged, and quantified. The bacterial cell pellet obtained was suspended in $15 \mathrm{~mL}$ broth minimal medium to obtain $0.72 \mathrm{OD}$ at $610 \mathrm{~nm}$. For batch degradation studies with free cells, $3 \mathrm{~mL}$ of cell suspension $(0.72 \mathrm{OD}$ at $610 \mathrm{~nm})$ was inoculated into 10 autoclaved $250 \mathrm{~mL}$ Erlenmeyer flasks with $29.5 \mathrm{~mL}$ of Broth minimal medium. The inoculated flasks were spiked with $17.5 \mathrm{~mL}$ of $1 \mathrm{ppm}$ endosulfan to give a final concentration of approximately $350 \mu \mathrm{g} / \mathrm{L}$. The initial $\mathrm{pH}$ was set to 7.0 to prevent chemical hydrolysis of endosulfan at an alkaline pH (Sutherland et al. 2000). The procedure was repeated using the control in the absence of any bacterial culture. All the flasks were incubated on a microbial shaker at $30^{\circ} \mathrm{C}$ at $150 \mathrm{rpm}$ for 18 days. At the end of 3,5 , $7,9,11,12,13,15,17$ and 18 days of incubation, samples from each flask were collected and analysed for endosulfan and its metabolites by extracting the samples using a hexane:acetone (80:20) mixture. The growth of Pseudomonas fluorescens cells was monitored by recording the OD of the culture at a wavelength of $610 \mathrm{~nm}$ for different time intervals during the study. Maximum bacterial growth was measured as $\mathrm{OD} / \mathrm{OD}_{0}$ ratios (optical density at given time/ optical density at the beginning of the experiment) for the endosulfan degradation assessments.

\subsection{Batch Degradation Study of Endosulfan with Immobilised Cells}

The study of the degradation of different concentrations of endosulfan using Pseudomonas cells immobilised with Ca-alginate beads was conducted in different batches. Endosulfan was added separately to each of the autoclaved Erlenmeyer flasks containing Broth minimal medium of $\mathrm{pH} 7.0$ to obtain final concentrations of approximately 350,450 and $550 \mu \mathrm{g} / \mathrm{L}$ of endosulfan. A total of $125 \mathrm{~mL}$ of Broth minimal medium of $\mathrm{pH} 7$ was inoculated with $5 \mathrm{~g}$ of wet Ca-alginate beads (derived from a $3 \mathrm{~mL}$ cell suspension of $0.72 \mathrm{OD}$ at $610 \mathrm{~nm}$ ). The average diameter of the beads was approximately $3 \mathrm{~mm}$. The alginate beads in $\mathrm{CaCl}_{2}$ solution was filtered and washed several times with $0.9 \% \mathrm{NaCl}$ to remove excess calcium ions, and entrapped cells were washed twice with deionised water (Ravichandra et al. 2008). These alginate beads were then suspended in each flask and incubated at $30{ }^{\circ} \mathrm{C}$ and $150 \mathrm{rpm}$ in a microbial shaker for 12 days. To monitor the degradation of endosulfan and generation of metabolites, $10 \mathrm{~mL}$ of culture was extracted using a hexane: acetone (80:20) mixture at regular 
intervals under sterile conditions. All the experiments were conducted in triplicate and control experiments were also maintained using empty $\mathrm{Ca}$-alginate beads that did not contain the microorganism. $\mathrm{pH}$ was also recorded during the experiment.

\subsection{Comparison Between the Efficiency of Free Cells and Immobilised Cells}

The efficiency of free cells and immobilised cells was compared at the same experimental conditions by using $0.068 \mathrm{~g}$ cells and the experiment was carried at $30{ }^{\circ} \mathrm{C}$ and $150 \mathrm{rpm}$. The contributions of free cells and immobilised cells toward endosulfan $(350 \mu \mathrm{g} / \mathrm{L})$ degradation were evaluated by eliminating the abiotic removal from the total endosulfan removed within 9 days of incubation by maintaining a control experiment.

\subsection{Packed Bed Column Study}

The feasibility of using a packed bed column for bio-degradation of endosulfan was studied under semi-continuous conditions. Two cylindrical glass columns $(450 \times 30 \mathrm{~mm})$ were used as the reactor. The total reactor volume was $282.60 \mathrm{~mL}$. Non-adsorbent cotton wool was placed at the bottom to support the bed. One of the columns was filled with cell-immobilised Caalginate beads up to $25 \mathrm{~cm}$ in height. The other column was used as a control and packed with empty Ca-alginate beads to the same height. The working volume of the reactor was $176.63 \mathrm{~mL}$. Then, $208 \mathrm{~mL}$ of sterile Broth minimal medium (pH 7.0) with $291.6 \mathrm{~mL}$ of $600 \mu \mathrm{g} / \mathrm{L}$ endosulfan was passed through the packed bed column at a $0.59 \mathrm{~mL} / \mathrm{min}$ flow rate for $10 \mathrm{~h}$ each day.

Column studies were conducted with cell-immobilised Ca-alginate beads after checking their efficiency through batch degradation studies. The two columns, one packed with alginateimmobilised cells and the other with Ca-alginate beads without the microorganism, were operated in a semi-continuous mode for $10 \mathrm{~h}$ each day. Broth mineral medium supplemented with $350 \mu \mathrm{g} / \mathrm{L}$ endosulfan was passed through the two columns at the rate of $0.59 \mathrm{~mL} / \mathrm{min}$. The columns were operated in this manner for 18 days. At this rate, the hydraulic retention time was $300 \mathrm{~min}$.

\subsection{Extraction of Endosulfan}

Endosulfan was extracted using a mixed extracting solvent of chromatographic grade n-hexane and acetone. The extraction of pesticide residues was carried out following standard methods (USEPA 1996; APHA 2005).

The endosulfan-containing sample $(10 \mathrm{~mL})$ was placed in a $250 \mathrm{~mL}$ conical flask, and $0.1 \mathrm{~mL} \mathrm{HCl}$ was added. The mixture was shaken well and then transferred into a separating funnel with a 250-mL capacity. Next, $10 \mathrm{~mL}$ of a hexane:acetone $(80: 20)$ mixture was added to the sample and shaken well for approximately $10 \mathrm{~min}$ and kept for layer separation. The aqueous layer was collected in a beaker. The n-hexane layer was transferred to a standard flask from the separating funnel. The procedure was repeated for the complete extraction of pesticide residues. Three grams of anhydrous sodium sulphate was added to the n-hexane layer for dehydration. Extracts were pooled and passed through a chromatography column containing anhydrous sodium sulphate $(5 \mathrm{~g})$ and alumina ( $7 \mathrm{~g}$ ) mixture with glass wool at the bottom to remove moisture and matrix interferences. The extract was then concentrated to $10 \mathrm{~mL}$ and stored in an ambercoloured vial. The extract was stored at $4{ }^{\circ} \mathrm{C}$ until analysis. 


\subsection{Analysis of Endosulfan Residues}

The samples, after processing and clean up, were analysed for endosulfan residues by gas chromatograph using an electron capture detector (GC-ECD). A Varian CP-3800 gas chromatograph equipped with a $\mathrm{Ni}$ electron capture detector was used for the analysis. The experimental conditions used for the estimation of endosulfan are reported in previous publications (Harikumar et al. 2013). The retention times for endosulfan alpha, endosulfan beta, endosulfan sulphate, endosulfan ether, endosulfan lactone and endosulfan diol were $18.73,21.94,24.15,12.30,16.9$ and $28.8 \mathrm{~min}$, respectively.

\subsection{TOC Analysis}

TOC analysis was performed using a TOC analyser from Hach using the TOC Direct Method. To analyse the TOC of endosulfan, $1 \mathrm{~mL}$ of extracted endosulfan and persulphate were added to the digestion tube. The persulphate and the digestion reagent will oxidise the endosulfan's carbon to carbon dioxide. An opened ampule of $\mathrm{pH}$ indicator reagent was inserted into the digestion tube, and the tube was sealed. For digestion, the assembled unit was kept at $103-105{ }^{\circ} \mathrm{C}$ for $2 \mathrm{~h}$. As a result, the carbon dioxide diffused into the inner ampule, forming carbonic acid. After cooling, the complete unit was placed into a TOC analyser and the value of total organic carbon was directly noted from the instrument. Organic-free water was also analysed.

\section{Results and Discussion}

\subsection{Method Validation for Endosulphan Residue Analysis Using Gas Chromatograph}

Results of validation and percentage recoveries are indicated in Tables 1 and 2. Table 1 summarizes the calibration data, the LODs and LOQs for the studied metabolites of endosulfan. LODs varied from 1.1 to $1.3 \mu \mathrm{g} / \mathrm{L}$ and LOQs ranged from 3.7 to $4.3 \mu \mathrm{g} / \mathrm{L}$. Average recoveries and relative standard deviations (RSD \%) at four concentrations are indicated in Table 2.

\subsection{Morphological and Biochemical Characterisation}

The Gram-negative Pseudomonas isolate was found to be fluorescent green on King's $\mathrm{B}$ medium under ultraviolet light at $365 \mathrm{~nm}$. The biochemical tests further confirmed the isolates to be Pseudomonas fluorescens. The results of biochemical tests are indicated in Table 3.

Genomic DNA was isolated from the bacteria isolated from soil sample using Sigma Aldrich DNA extraction Kit. Its quality was evaluated on $0.8 \%$ Agarose Gel. A single band of high-molecular weight DNA was observed. Further 16S rDNA was amplified by PCR from the above isolated genomic DNA. A single discrete band was observed when resolved on Agarose Gel. The PCR amplicon was purified by column purification in order to remove contaminants. DNA sequencing was carried out with PCR amplicon. The 16S rDNA sequence was used to carry out BLAST with the nrs database of NCBI genbank database (Fig. 1). Based on the BLAST output and similarity with 16S rDNA-PCR analysis the bacteria showed $99 \%$ similarity with Pseudomonas fluorescens. 
Table 1 Validation results: Limit of detection and limit of quantification

\begin{tabular}{llc}
\hline Pesticide & LOD $(\mu \mathrm{g} / \mathrm{L})$ & LOQ $(\mu \mathrm{g} / \mathrm{L})$ \\
\hline Endosulfan alpha & 1.2 & 4.0 \\
Endosulfan beta & 1.1 & 3.7 \\
Endosulfan diol & 1.3 & 4.3 \\
Endosulfan ether & 1.2 & 4.0 \\
Endosulfan lactone & 1.1 & 3.7
\end{tabular}

\subsection{Endosulfan Degradation by Free Cells of Pseudomonas fluorescens}

The degradation of endosulfan by Pseudomonas fluorescens was determined at an initial endosulfan concentration of $350.24 \pm 0.83 \mu \mathrm{g} / \mathrm{L}$ by monitoring its disappearance over a period of 12 days of incubation at $30{ }^{\circ} \mathrm{C}$ and $150 \mathrm{rpm}$, at regular time intervals. To check the abiotic loss of endosulfan, control experiments of uninoculated flasks with endosulfan were also maintained under similar conditions. There was a gradual decrease in the endosulfan concentration until the end of the 12th day of study, which is indicated in Fig. 2. All the results presented are the mean of three replicate experiments.

Complete degradation $(\sim 100 \%)$ of the spiked amount of endosulfan was observed within 12 days in the inoculated condition, whereas only $11.15 \pm 0.52 \%$ degradation was observed in uninoculated flasks, indicating that only minimal chemical degradation or volatilisation of endosulfan had occurred. From the results of the control experiments, it was clear that about $88.9 \%$ of endosulfan was retained even after 12 days. It would be expected to take more than 100 days for the complete removal of endosulfan through the natural degradation process. From the observations, it was evident that the complete removal of endosulfan within 12 days of incubation is mainly due to the presence of Pseudomonas fluorescens cells.

\subsection{Estimation of Microbial Growth}

Pseudomonas fluorescens had no lag phase because the bacteria were harvested from the culture medium containing endosulfan. The bacterial species might have adapted itself in the medium quickly and utilised endosulfan as a carbon source. The results revealed that the biomass of the Pseudomonas fluorescens culture increased gradually during the first 12 days without any lag phase and reached the maximum $\mathrm{OD} / \mathrm{OD}_{0}$ value of 1.68 at the end of the 12 th day. This observed increase in $\mathrm{OD} / \mathrm{OD}_{0}$ along with the degradation of endosulfan indicated the

Table 2 Average recoveries and relative standard deviations (RSD \%) at four concentration levels $(n=4)$

\begin{tabular}{|c|c|c|c|c|c|c|c|c|}
\hline \multirow[t]{2}{*}{ Pesticide } & \multicolumn{2}{|l|}{ LOD } & \multicolumn{2}{|c|}{$50(\mu \mathrm{g} / \mathrm{L})$} & \multicolumn{2}{|c|}{$100(\mu \mathrm{g} / \mathrm{L})$} & \multicolumn{2}{|c|}{$150(\mu \mathrm{g} / \mathrm{L})$} \\
\hline & $\% \mathrm{R}$ & $\%$ RSD & $\% \mathrm{R}$ & $\% \mathrm{RSD}$ & $\% \mathrm{R}$ & $\%$ RSD & $\% \mathrm{R}$ & $\%$ RSD \\
\hline Endosulfan alpha & 96.6 & 1.9 & 98.7 & 2.0 & 91.6 & 1.5 & 96.5 & 0.8 \\
\hline Endosulfan beta & 99.8 & 2.8 & 95.7 & 2.3 & 96.7 & 2.3 & 91.2 & 3.7 \\
\hline Endosulfan diol & 97.5 & 3.2 & 94.6 & 1.2 & 93.4 & 3.4 & 94.6 & 2.6 \\
\hline Endosulfan ether & 94.8 & 2.4 & 93.9 & 2.6 & 90.2 & 4.2 & 90.6 & 3.4 \\
\hline Endosulfan lactone & 96.5 & 1.6 & 96.8 & 3.4 & 94.6 & 3.2 & 96.7 & 2.3 \\
\hline
\end{tabular}


Table 3 Biochemical characterization of Pseudomonas fluorescens isolates

\begin{tabular}{lll}
\hline No. & Parameters & Isolates of Pseudomonas fluorescens \\
\hline 1 & Gram staining & Negative \\
2 & Gelatin liquefaction & Positive \\
3 & Catalase test & Positive \\
4 & Oxidase test & Positive \\
5 & Starch hydrolysis & Negative \\
6 & Fluorescent pigment & Positive \\
7 & Estimation of IAA $(\mu \mathrm{g} / \mathrm{ml})$ & 3.6 \\
8 & Siderophore production $($ Hydroxamate) & 0.86 \\
9 & Hydrogen cyanide production & 8.13 \\
\hline
\end{tabular}

consumption of endosulfan as a carbon and energy source (Awasthi et al. 1997; Sutherland et al. 2000; Siddique et al. 2003). There was no further increase in biomass after the 12th day. A slight decrease in growth was observed from the 12th day of incubation to the 14th day of incubation, after which the growth was found to decrease gradually.

\subsection{Batch Degradation Study of Endosulfan Using Ca-Alginate-Immobilised Cells}

The colony formation of the bacterial species inside Ca-alginate beads was confirmed using scanning electron microscopic analysis. The SEM images of empty Ca-alginate beads and Pseudomonas fluorescens cell-immobilised Ca-alginate beads are indicated in Fig. 3. The bacterial colonies that formed inside the pores of Ca-alginate beads can be clearly observed in Fig. 3b, whereas empty pores are observed in Fig. 3a.

Degradation of different concentrations of endosulfan viz. $350.24 \pm 0.83,450.39 \pm 1.95$ and $550.85 \pm 1.84 \mu \mathrm{g} / \mathrm{L}$ was studied using Ca-alginate beads. The controls of different concentrations of endosulfan were set up separately, with the Broth minimal medium containing $5 \mathrm{~g}$ empty wet Ca-alginate beads.

н1

H1

H1

н1

H1

H1

H1

1

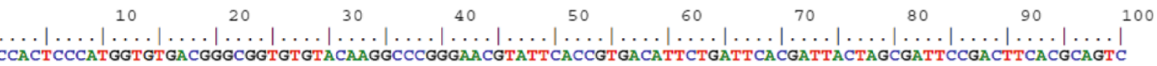
$\begin{array}{llllllllll}110 & 120 & 130 & 140 & 150 & 160 & 170 & 180 & 190 & 200\end{array}$

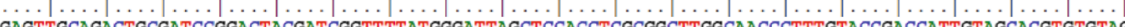
GAGTGCAGACTGCGATCCGGACTACGATCGGTTTTATGGGATTAGCTCCACCTCGCGGCTTGGCAACCCTTTGTACCGACCATTGTAGCACGTGTGTAG 210
$\ldots|\ldots| \ldots|\ldots| \ldots|\ldots| \ldots|\ldots| \ldots|\ldots| \ldots|\ldots| \ldots|\ldots| \ldots|\ldots| \ldots|\ldots| \ldots|\ldots| \ldots|\ldots| \ldots|\ldots| \ldots|\ldots| \ldots|\ldots|$ CCCTGGCCGTAAGGGCATGATGA TTGA CGTCATCCCCA CCTTCCTCCGGTTTGTCACCGGCA GTCTCCTTAGAGTGCCCACCCGAGGTGCTGGTAACT $\begin{array}{llllllllll}310 & 320 & 330 & 340 & 350 & 360 & 370 & 380 & 390 & 400\end{array}$ $\ldots|\ldots| \ldots|\ldots| \ldots|\ldots| \ldots|\ldots| \ldots|\ldots| \ldots|\ldots| \ldots|\ldots| \ldots|\ldots| \ldots|\ldots| \ldots|\ldots| \ldots|\ldots| \ldots|\ldots| \ldots|\ldots| \ldots \mid$ $\begin{array}{llllllllll}410 & 420 & 430 & 440 & 450 & 460 & 470 & 480 & 490 & 500\end{array}$ $\ldots|\ldots| \ldots|\ldots| \ldots|\ldots| \ldots|\ldots| \ldots|\ldots| \ldots|\ldots| \ldots|\ldots| \ldots|\ldots| \ldots|\ldots| \ldots|\ldots| \ldots|\ldots| \ldots|\ldots| \ldots|\ldots|$ AATCCATCTCTGGAAATTCTCAGCATGTCAAGGCAGGTAAGGTCTTCGCGTGCTTCGAATTAAACCA CATGCTCCACCGCTTGTGCGGGCCCCGT

$\begin{array}{lllllllll}510 & 520 & 530 & 540 & 550 & 560 & 570 & 580 & 590\end{array}$

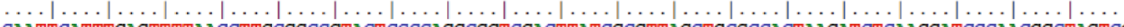
$\begin{array}{llllllllll}610 & 620 & 630 & 640 & 650 & 660 & 670 & 680 & 690 & 700\end{array}$ $\ldots|\ldots| \ldots|\ldots| \ldots|\ldots| \ldots|\ldots| \ldots|\ldots| \ldots|\ldots| \ldots|\ldots| \ldots|\ldots| \ldots|\ldots| \ldots|\ldots| \ldots|\ldots| \ldots|\ldots| \ldots|\ldots| \ldots \mid$

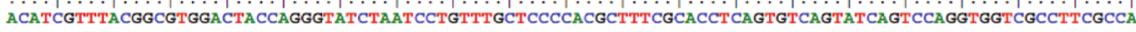

\begin{tabular}{|l|l|l|l|l|l|l|l|l}
710 & 720 & 730 & 740 & 750 & 760 & 770 & 780 & 790
\end{tabular} CTGGTGTTCCTTCCTATATCTACGCATTTCACCGCTACACA $\ldots|\ldots| \ldots|\ldots| \ldots|\ldots| \ldots|\ldots| \ldots|\ldots| \ldots|\ldots| \ldots|\ldots| \ldots|\ldots| \ldots|\ldots|$

Fig. 1 Consensus Sequence Data of bacteria (1000 bp) 


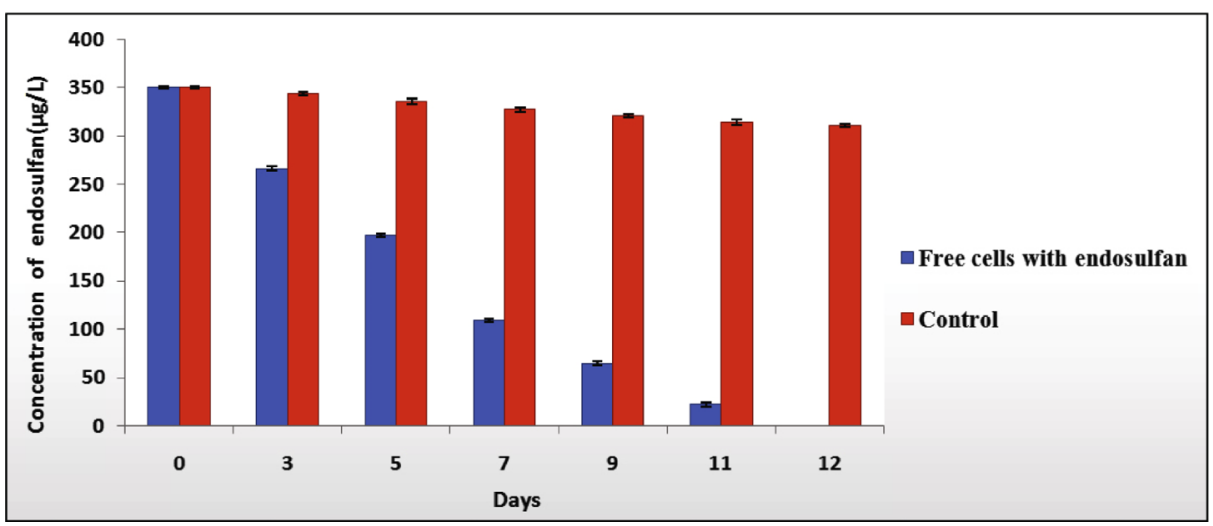

Fig. 2 Comparison of the decrease in endosulfan concentration in the control and biodegradation study using free Pseudomonas fluorescens cells

Figure 4 shows the decrease in concentration of endosulfan with time for the endosulfan concentrations tested. The results indicated a similar trend of degradation for different initial endosulfan concentrations, ranging from 350 to $550 \mu \mathrm{g} / \mathrm{L}$. From the graph, it is clear that the degradation was the greatest in the first 3 days, followed by a gradual reduction, which can likely be attributed to the availability of the biomass and its need to consume a carbon and energy source. The complete degradation of endosulfan in the immobilised system under batch conditions was observed in 9 days for both the initial endosulfan concentrations of 350 and $450 \mu \mathrm{g} / \mathrm{L}$. The initial endosulfan concentration of $550 \mu \mathrm{g} / \mathrm{L}$ required 11 days for complete removal. This may be due to the higher concentration of endosulfan present which required greater time for the bacterial cells to degrade it.

The immobilised cells degraded approximately $85.62 \pm 0.32 \%$ of the endosulfan after 7 days of incubation from an initial $350.24 \pm 0.83 \mu \mathrm{g} / \mathrm{L}$ of endosulfan. Almost similar trends in degradation efficiencies were obtained when the initial concentrations were $450.39 \pm 1.95$
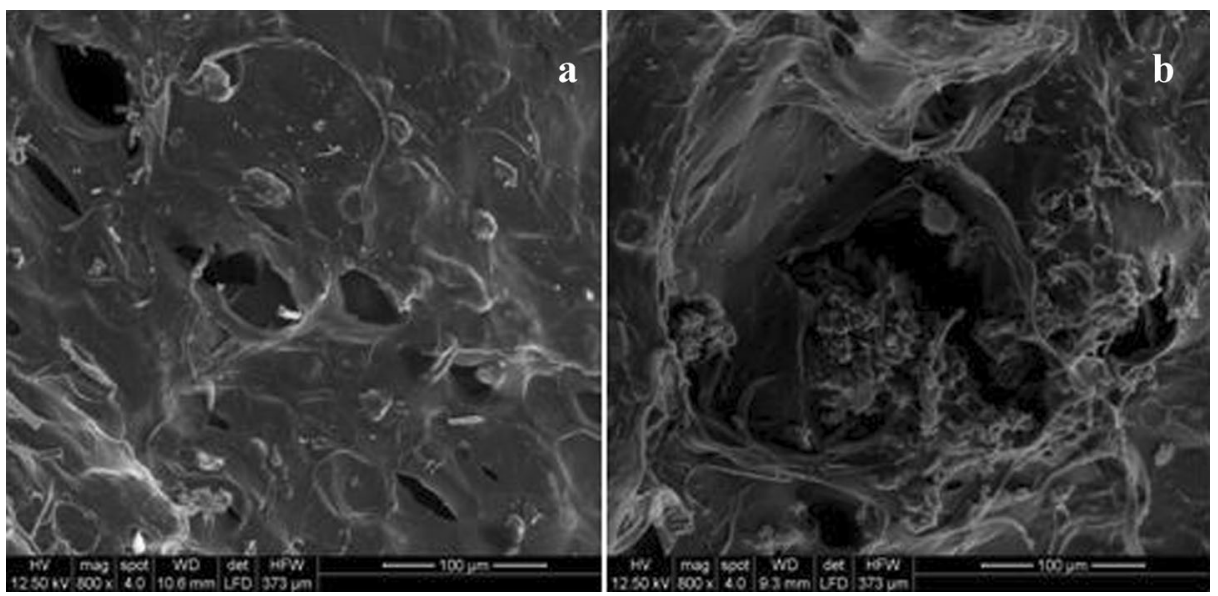

Fig. 3 SEM photomicrographs of Ca-alginate beads (a) and cell-immobilised Ca-alginate beads (b) 


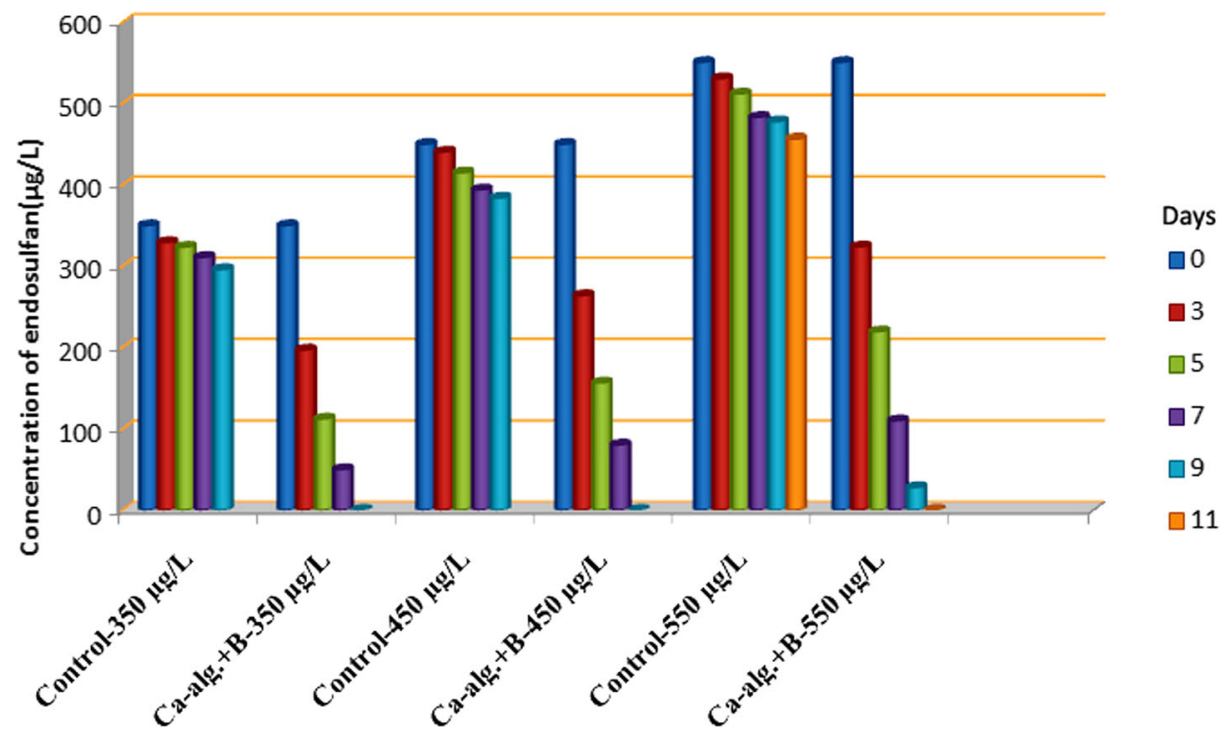

Fig. 4 Decrease in the concentration of endosulfan in batch degradation studies using Ca-alginate beads (alg. denotes alginate, $\mathrm{B}$ denotes bacterial cells)

and $550.85 \pm 1.84 \mu \mathrm{g} / \mathrm{L}$ of endosulfan $(82.11 \pm 0.24$ and $79.97 \pm 0.27 \%$, respectively). But there was a decrease in degradation process after 10 days when the reactor was operated at higher initial endosulfan concentration $(550 \mu \mathrm{g} / \mathrm{L})$ and this can be related to the higher concentration of endosulfan beta formed during the degradation. This might have caused reduction in the microbial capability of degrading this chemical (Elsaid et al. 2014).

When the process was evaluated using empty beads without the microorganisms, the endosulfan removal capacities due to adsorption and volatilisation were found to be $15.44 \pm$ $0.71,14.71 \pm 0.44$ and $13.26 \pm 0.24 \%$ for the initial endosulfan concentrations of $350.24 \pm 0.83$, $450.39 \pm 1.95$ and $550.85 \pm 1.84 \mu \mathrm{g} / \mathrm{L}$ in the medium, respectively, within 9 days. The removal efficiency of endosulfan in the presence of microorganisms was found to be much higher than the degradation in the control medium.

\subsection{Comparison Between the Efficiency of Free and Immobilised Cells}

The efficiency of free cells and immobilised cells in degrading endosulfan was compared using a batch of free cells and the same amount of cells immobilised in Ca-alginate beads. The increased substrate removal with Ca-alginate cells compared to free cells has been reported by many scientists (Keweloh et al. 1989; Rhee et al. 1996; Manohar et al. 2001). In the present study, the immobilised cells possessed a higher degradation capacity at the initial endosulfan concentration of $350 \mu \mathrm{g} / \mathrm{L}$ than free cells, even though the cell contents in both free cells and immobilised cells were similar. This revealed that the degradation rate was approximately $11.3 \%$ higher for immobilised cells and they could remove endosulfan completely within 9 days. At the same conditions, free cells took 12 days for complete removal. The efficiency of free and immobilised cells is compared in Table 4. From the results, it can be concluded that Ca-alginate immobilisation has increased cell survival and metabolic activity in the bioremediation system (Tao et al. 2009; Moslemy et al. 2002). 
Table 4 Percentage contribution of the free and immobilized cells towards endosulfan degradation

\begin{tabular}{lll}
\hline Treatment & $\begin{array}{l}\text { Removal of endosulfan } \\
\text { after nine days }(\%)\end{array}$ & $\begin{array}{l}\text { Contribution of bacterial cells } \\
\text { towards the degradation }(\%)\end{array}$ \\
\hline Control of Free cells & $8.22 \pm 0.54$ & 73.31 \\
Free cells & $81.56 \pm 0.67$ & \\
Control of immobilized cells & $15.44 \pm 0.71$ & 84.56 \\
Immobilized cells & $\approx 100$ & \\
\hline
\end{tabular}

\subsection{Degradation of Endosulfan in a Packed Bed Reactor}

Decreases in the endosulfan concentration were checked at regular intervals of time (days). There was no significant change in the endosulfan concentration when the column remained static without any feed. Bacteria often have a very narrow $\mathrm{pH}$ interval with neutral or slightly alkaline conditions favoured (Rousk et al. 2009; Bending et al. 2003). Though neutral pH was maintained, the cell immobilised calcium alginate beads were found to remain stable throughout the experiment.

This study shows the feasibility of using alginate-immobilised cells of Pseudomonas fluorescens for the degradation of endosulfan in a packed bed reactor. Figure 5 shows approximately $100 \%$ removal of endosulfan in the column packed with cell-immobilised Ca-alginate beads during the 6th day of experiment. On the sixth day, only $18.20 \pm 0.52 \%$ decrease in the concentration was observed due to adsorption and volatilisation in the column with empty Ca-alginate beads. A rapid decrease in the endosulfan concentration (67.68 \pm $0.36 \%$ ) occurred during the first 2 days of the experiment. This rapid removal of endosulfan is mainly due to the presence of the high cell concentration in Ca-alginate beads, which is derived from the $0.34 \mathrm{~g}$ of wet cells. Also, the decrease in endosulfan degradation performance with time may be due to the variation in biomass concentration.

In the column experiments, endosulfan alpha and endosulfan beta were found to be below the detection limit within 6 days. However, the experimental study was continued to discover the time necessary for complete degradation of endosulfan. Monitoring of endosulfan residues on the 18th day revealed that complete degradation of endosulfan had occurred because no

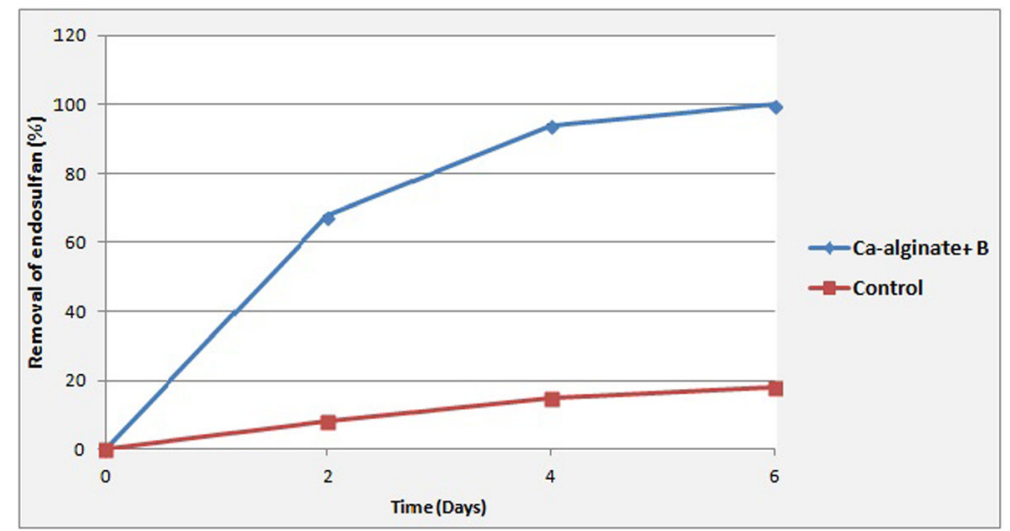

Fig. 5 Percentage removal of endosulfan during the column experiment 
intermediate metabolites of endosulfan were detected through bioremediation using Pseudomonas fluorescens.

Degradation of some chlorinated pesticides like 2, 4-D (2, 4 dichlorophenoxyacetic acid) and DDT (Dichlorodiphenyltrichloroethane) using immobilized Pseudomonas fluorescens has already been reported. Pesticide removals for 2, 4-D was about $99 \%$. DDT removal was as high as 55-99\% (Santacruz et al. 2005). Hence, the potential of the strain in degrading endosulfan was further studied. Also several studies on the degradation of endosulfan using mixed bacterial cultures have been reported. The degradation of endosulfan (with initial concentration of $50 \mathrm{mg} / \mathrm{L}$ ) by mixed bacterial culture was studied and after 3 weeks of incubation, the mixed culture was able to degrade $71.58 \pm 0.2$ and $75.88 \pm 0.2 \%$ in aerobic and facultative anaerobic conditions, respectively (Kumar and Philip 2006a, b). Studies conducted with free cells of Pseudomonas fluorescens reported degradation of $10 \mathrm{mg} / \mathrm{L}$ of heptachlor, heptachlor epoxide, aldrin, and dieldrin with maximum removals of 98.42, 90.77, 99.84 and $91.33 \%$, respectively (Bandala et al. 2002). Degradation of mono-, di-, tri-, and penta-chlorophenols at concentrations of up to 500,500,400, and $200 \mathrm{mg} / \mathrm{L}$ using the Pseudomonas fluorescens strain, immobilized in tezontle columns were also reported (Torres et al. 1999). The present study aimed at the degradation of endosulfan using a single isolated species and the results proved that Pseudomonas fluorescens can be utilized for complete degradation of endosulfan.

\subsection{Integrity of Ca-Alginate Beads}

It has been previously reported that the mechanical instability and gradual cell leakage from the beads decreases the degradation rate with increased cycle number (Trevors et al. 1992). However, here, the Ca-alginate beads showed no signs of breaking up or disintegrating. It appeared that the Ca-alginate beads maintained their integrity until the end of the experiment for both batch and semi-continuous column experiments. This may be due to the better cell holding capacity and flexibility of the Ca-alginate gel that allowed accommodation of more cells that were generated during cell growth.

\subsection{Pathway Identification}

The Total Organic Carbon (TOC) determination of endosulfan at regular time intervals of the column study was used to establish the phenomenon of complete mineralisation (Santacruz et al. 2005). Regarding the TOC degradation, the typical profile of mineralisation of endosulfan as a function of time is shown in Fig. 6. TOC of $32.94 \%$ was observed during the first 6 days of the experiment for the initial $350 \mu \mathrm{g} / \mathrm{L}$ endosulfan concentration. This would explain the approximately $32.94 \%$ concentration of endosulfan that has been converted into simple metabolites such as $\mathrm{CO}_{2}$.

Column experiments were used to identify the metabolic pathway of endosulfan degradation by monitoring the formation of endosulfan metabolites by GC-ECD. Monitoring was continued until the 18th day of experiment at which the complete removal of endosulfan has taken place. Endosulfan diol, endosulfan ether, and endosulfan lactone were detected by GC analysis using authentic standards and matching the retention time (Table 5). Formation of these metabolites has been reported previously (Weir et al. 2006; Shivaramaiah and Kennedy 2006). Endosulfan diol, which is less toxic, was detected as the major metabolite during the study. A chromatogram showing endosulphan alpha, endosulfan beta, endosulfan ether, endosulfan lactone, and endosulfan diol is indicated in Fig. 7. The presence of metabolites indicated that endosulfan degradation with Pseudomonas fluorescens cells occurred through 


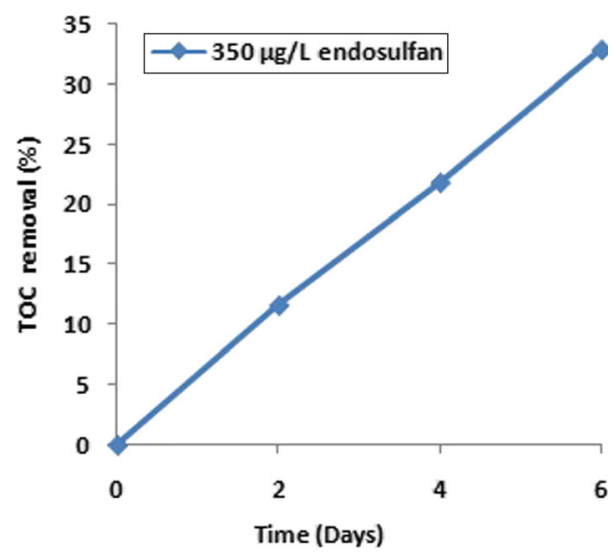

Fig. 6 Percentage removal of TOC during degradation of endosulfan

the hydrolytic pathway, in which endosulfan was converted into endosulfan lactone via endosulfan diol and endosulfan ether. The $\mathrm{pH}$ of the medium was maintained between 6.8 and 7.0 throughout the experiment to prevent chemical hydrolysis. No metabolites were detected in the control study with empty Ca-alginate beads.

The amount of toxic isomers of endosulfan that was dissipated could not be accounted by the total concentration of metabolites detected during the experiment. This finding suggests that the complete mineralisation of a certain fraction of endosulfan might have occurred (Kumar and Philip 2006a, b). The results showed a fluctuation of endosulfan beta concentration during degradation process. A portion of endosulfan alpha during the degradation process might have been converted to endosulfan beta. There is a chance of inter-conversion of the two isomers even when specific conditions are maintained (Mukherjee and Gopal 2006).

All of the samples collected as part of the biodegradation study were analysed with GCECD. Within 6 days of the column experiments using Pseudomonas fluorescens immobilised in Ca-alginate beads, the toxic isomers of endosulfan (endosulfan alpha and endosulfan beta) were found to be below the detection limit. Intermediate metabolites of endosulfan, endosulfan diol, endosulfan ether, and endosulfan lactone were also detected during the study. Monitoring of endosulfan residues on the 18th day revealed that complete degradation of endosulfan had occurred because no other metabolite of endosulfan was detected. Endosulfan might have been

Table 5 Concentration of endosulfan isomers and their metabolites detected at different intervals during the degradation of endosulfan

\begin{tabular}{lccccc}
\hline $\begin{array}{l}\text { Time period } \\
\text { (days) }\end{array}$ & \multicolumn{4}{l}{ Concentration of parent isomers and their metabolites $(\mu \mathrm{g} / \mathrm{L})$} & \\
\cline { 2 - 5 } & $\begin{array}{l}\text { Endosulfan } \\
\text { alpha }\end{array}$ & $\begin{array}{l}\text { Endosulfan } \\
\text { beta }\end{array}$ & $\begin{array}{l}\text { Endosulfan } \\
\text { diol }\end{array}$ & $\begin{array}{l}\text { Endosulfan } \\
\text { ether }\end{array}$ & $\begin{array}{l}\text { Endosulfan } \\
\text { lactone }\end{array}$ \\
\hline 0 & 248.82 & 101.55 & BDL & BDL & BDL \\
2 & 112.79 & 0.44 & 190.51 & 1.83 & 2.27 \\
4 & 10.59 & 1097 & 250.01 & 2.11 & 4.33 \\
6 & BDL & BDL & 225.28 & 3.85 & 5.83 \\
\hline
\end{tabular}

$B D L$ Below detection limit 


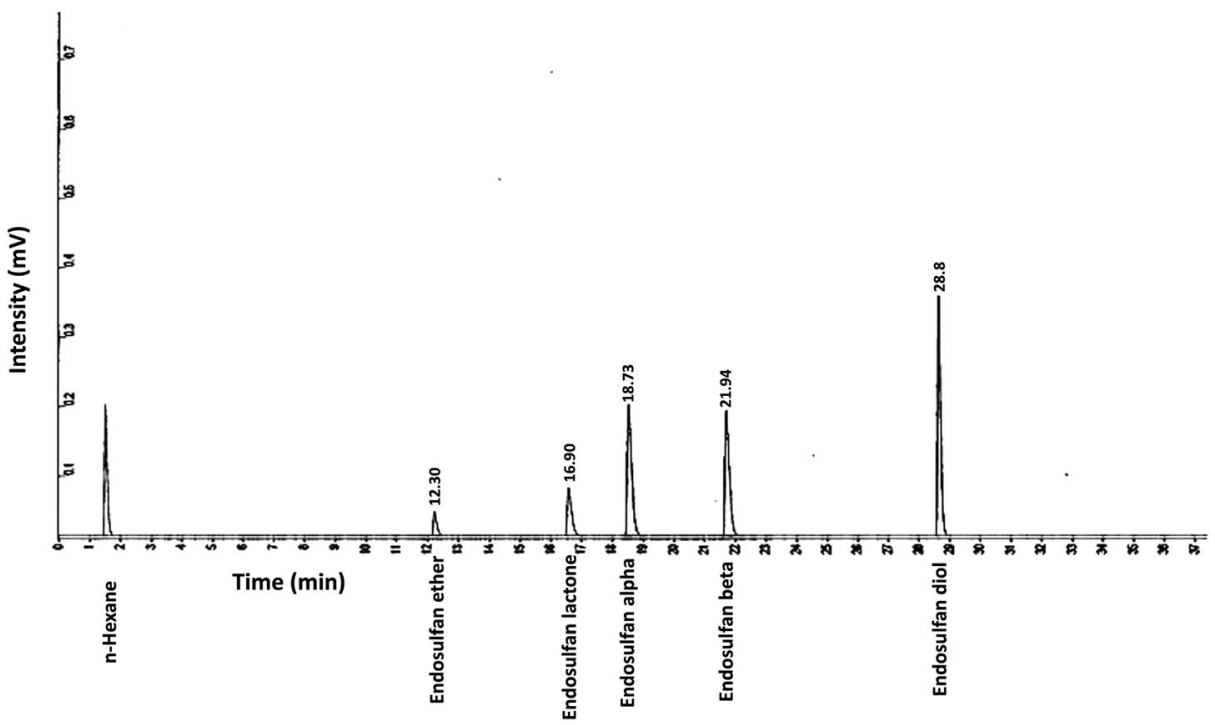

Fig. 7 Chromatogram showing the retention times of endosulfan alpha, endosulfan beta, endosulfan ether, endosulfan lactone and endosulfan diol

degraded via hydrolysis through the formation of different metabolites, and finally converted to carbon dioxide (Kumar and Philip 2006a, b). Thus, endosulfan was found to be completely degraded in 18 days, using Pseudomonas microbial strains. This was the major pathway for the degradation of endosulfan. TOC studies also indicated the possibility of a minor pathway for the complete mineralisation of endosulfan to $\mathrm{CO}_{2}$. The results of the study implied that the bacterial strains could be employed for bioremediation of environments polluted by

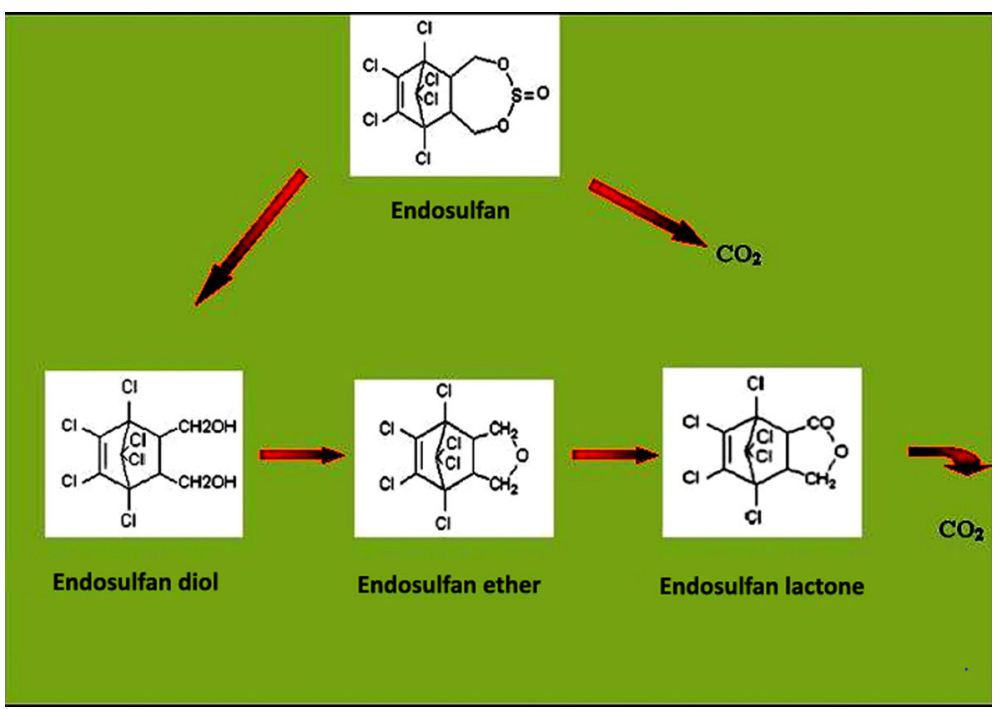

Fig. 8 Proposed pathway of endosulfan degradation by Pseudomonas fluorescens 
endosulfan. The pathway proposed for the degradation of endosulfan on the basis of this study is depicted in Fig. 8.

\section{Conclusion}

The bacterial strain Pseudomonas fluorescens was found to be efficient for the removal of endosulfan. The highest pesticide biodegradation was obtained in a packed bed column reactor with the bacterial species immobilised in Ca-alginate beads. The presence of intermediate metabolites formed during the study was confirmed, and the metabolites were identified as endosulfan diol, endosulfan ether and endosulfan lactone. These metabolites suggested a hydrolytic pathway for the biodegradation of endosulfan using Pseudomonas fluorescens species. The present study on the microbial degradation of endosulfan by Pseudomonas fluorescens may provide a basis for the development of bioremediation strategies to remediate pollutants in the environment.

Acknowledgement K. Jesitha thanks Women Scientists Division of the Kerala State Council for Science Technology and Environment for financial support through the Back to Lab Programme

\section{References}

APHA (2005) Standard methods for the examination of water and wastewater, 21st edn. American Public Health Association, Washington

Awasthi N, Manickam N, Kumar A (1997) Biodegradation of endosulfan by a bacterial coculture. Bull Environ Contam Toxicol 59:928-993

Bandala ER, Gelover S, Leal MT, Arancibia-Bulnes C, Jimenez A, Estrada C (2002) Solar photocatalytic degradation of aldrin. Catal Today 76:189-199

Bending GD, Lincoln SD, Sorensen SR, Morgan JA, Aamand J, Walker A (2003) In-field spatial variability in the degradation of the phenyl-urea herbicide isoproturon is the result of interactions between degradative Sphingomonas spp. and soil pH. Appl Environ Microbiol 69:827-834

BIS (2012) Indian standard drinking waters specification. Second revision. Bureau of Indian Standards, Manak Bhavan, New Delhi

Buchannan RE, Gibbson NE (1974) Bergeys manual of determinative bacteriology, 8th edn. Williams and Wilkins Co, Baltimore

Chen W, Georgiou G (2002) Cell-surface display of heterologous proteins: from high throughput screening to environmental applications. Biotechnol Bioeng 5:496-503

Elsaid OG, Abdelbagi AO, Elsheikhc EAM (2014) Microbial degradation of high endosulfan concentrations in carbon free media. International Conference on Biological, Civil and Environmental Engineering (BCEE2014), March 17-18, Dubai

Fernandez MF (2007) Human exposure to endocrine-disrupting chemicals and prenatal risk factors for cryptorchidism and hypospadias:a nested case-control study. Environ Health Perspect 115:8-14

Harikumar PS, Jesitha K, Sreechithra M (2013) Remediation of endosulfan by biotic and abiotic methods. J Environ Prot 4:418-425

Harikumar PS, Jesitha K, Megha T, Kokkal K (2014) Persistence of endosulfan in selected areas of Kasaragod District, Kerala. Curr Sci 106:1421-1429

Jia H, Liu L, Sun Y, Sun B, Wang D, Su Y, Kannan K, Li Y (2010) Monitoring and modeling endosulfan in Chinese surface soil. Environ Sci Technol 44:9279-9284

Keweloh H, Heipieper HJ, Rehm HJ (1989) Protection of bacteria against toxicity of phenol by immobilisation in calcium alginate. Appl Microbiol Biotechnol 31:383-389

Kierstan MPJ, Coughlan MP (1985) Immobilisation of cells and enzymes by gel entrapment. In: Woodward (ed) Immobilised cells and enzymes a practical approach. IRL Press, Oxford, pp 39-54

Kumar M, Philip L (2006a) Bioremediation of endosulfan contaminated soil and water- optimization of operating conditions in laboratory scale reactors. J Hazard Mater B 136:354-364 
Kumar M, Philip L (2006b) Enrichment and isolation of a mixed bacterial culturefor complete mineralisation of endosulfan. J Environ Sci Health B 41:81-96

Leena S, Choudhary SK, Singh PK (2011) Organochlorine and organophosphorous pesticides residues in water of River Gangaat Bhagalpur, Bihar, India. Int J Res Chem Environ 1:77-84

Manohar S, Kim CK, Karegoudar TK (2001) Enhanced degradation of napthalene by immobilization of Pseudomonas sp. strain NGK1 in polyurethane foam. Appl Microbiol Biotechnol 55:311-316

Meera T, Balabaskar P (2012) Isolation and characterisation of Pseudomonas fluorescens from rice fields. Int J Food Agric Vet Sci 2:113-120, ISSN: 2277-209X

Meleiro-Porto AL, Zelayarán MG, Consiglio Kasemod el M, Nitschke M (2011) Biodegradation of pesticides. In: Stoytcheva M (ed) Pesticides in the modern world-pesticides use and management. InTech, Croatia, pp 408-438

Moslemy P, Guiot SR, Neufeld RJ (2002) Production of size-controlled gellan gum microbeads encap -sulating gasoline-degrading bacteria. Enzym Microb Technol 30:10-18

Mukherjee I, Gopal M (2006) Interconversion of stereoisomers of endosulfan on chickpea crop under field conditions. Pestic Sci 40:103-106. doi:10.1002/ps.2780400203

$\mathrm{NIOH}$ (2002) Final report of the investigation of unusual illnesses allegedly produced by endosulfan exposure in Padre village of Kasaragod district (N. Kerala). National Institute of Occupational Health, Indian Council of Medical Research, Ahmedabad

Prasad MNV (2011) A State-of-the-art report on bioremediation, its applications to contaminated sites in India. Ministry of Environment \& Forests, Government of India, India

Ravichandra P, Gopal M, Annapurna J (2008) Biological sulfide oxidation using autotrophic Thiobacillus sp. evaluation of different immobilisation methods and bioreactors. J Appl Microbiol 106:1280-1291

Rhee SK, Lee GM, Lee ST (1996) Influence of a supplementary carbon source on biodegradation of pyridine by freely suspended and immobilised Pimelobacter sp. Appl Microbiol Biotechnol 44:816-822

Richins R, Mulchandani A, Chen W (2000) Expression, immobilisation, and enzymatic characterisation of cellulose-binding domain-organophosphorus hydrolase fusion enzymes. Biotechnol Bioeng 69:591-596

Rousk J, Brookes PC, Baath E (2009) Contrasting soil pH effects on fungal and bacterial growth suggest functional redundancy in carbon mineralization. Appl Environ Microbiol 75:1589-1596

Santacruz G, Bandala ER, Torres LG (2005) Chlorinated pesticides (2,4-D and DDT) biodegradation at high concentrations using immobilised Pseudomonas fluorescens. J Environ Sci Health B 40:571-583. doi:10. 1081/PFC-200061545

Shivaramaiah HM, Kennedy IR (2006) Biodegradation of endosulfan by a soil bacterium. J Environ Sci Health B 41:895-905

Siddique T, Benedict CO, Muhammad A, William TF (2003) Biodegradation kinetics of endosulfan by Fusarium ven-tricosum and a Pandoraea sp. J Agric Food Chem 51:8015-8019

Sinha RK, Valani D, Sinha S, Singh S, Heart S (2009) Bioremediation of contaminated sites: a low-cost nature's biotechnology for environmental clean up by versatile microbes, plants and earthworms. In: Faerber T, Herzog J (eds) Solid waste management and environmental remediation. Nova Science Publishers, Inc, Commack, pp 1-72

Sutherland TD, Horne I, Lacey MJ, Harcourt RL, Russel RJ, Oakeshott JG (2000) Enrichment of an endosulfandegrading mixed bacterial culture. Appl Environ Microbiol 66:2822-2828

Tao XQ, Lu GN, Liu JP, Li T, Yang LN (2009) Rapid degradation of phenanthrene by using Sphingomonas sp. GY2B immobilised in calcium alginate gel beads. Int J Environ Res Public Health 6:2470-2480

Tewari L, Malviya P (2002) Biodegradation of catechol by fluorescent Pseudomonas for sustainable environment. J Sci Ind Res 61:70-74

Torres LG, Santacruz G, Bandala ER (1999) Biodegradation of 2,4-D and DDT at high concentrations in lowcost packaging biofilters. In: Allem BC, Leeson E (eds) Bioremediation of nitroaromatic and haloaromatic compounds. Battelle, Columbus, pp 137-143

Trevors JT, Van Elsas JD, Lee H, Van Overbeek LS (1992) Use of alginate and other carriers for encapsulation of microbial cells for use in soil. Microb Releases 1:61-69

USEPA (1996) Methods for organic chemical analysis of municipal and industrial wastewater. United States Environmental Protection Agency, Washington, EPA -821-B-96-005

USEPA (2002) Reregistration eligibility decision for endosulfan. United States Environmental Protection Agency, Washington, EPA 738-R-02-013

Weir KM, Sutherland TD, Horne I, Russell RJ, Oakeshott JG (2006) A single monooxygenase, ese, is involved in the metabolism of the organochlorides endosulfan and endosulfate in an Arthrobacter sp. Appl Environ Microbiol 72:3524-3530

Zhao M, Zhang Y, Wang C, Fu Z, Liu W, Gan J (2009) Induction of macrophage apoptosis by an organochlorine insecticide acetofenate. Chem Res Toxicol 22:504-510 